\title{
Escherichia coli and Salmonella ser. Saintpaul natural co-infection in a free-living ruddy ground dove (Columbina talpacoti): a case report
}

\author{
[Coinfecção por Escherichia coli e Salmonella ser. Saintpaul em \\ Columbina talpacoti: relato de caso] \\ W.G.A. Bezerra ${ }^{1}$, R.V. Horn ${ }^{1}$, I.N.G. Silva ${ }^{1}$, R.A.S. Siqueira ${ }^{2}$, R.B. Lucena ${ }^{2}$, \\ A. Havt ${ }^{3}$, P.H.Q.S. Medeiros ${ }^{3}$, W.C. Maciel ${ }^{1}$ \\ ${ }^{1}$ Universidade Estadual do Ceará - UECE - Fortaleza, CE \\ ${ }^{2}$ Universidade Federal da Paraíba - UFPB - Areia, PB \\ ${ }^{3}$ Universidade Federal do Ceará - UFC - Fortaleza, CE
}

\begin{abstract}
This study reports a co-infection of Escherichia coli and Salmonella in a free-living ruddy ground dove (Columbina talpacoti) received at the Laboratory of Ornithological Studies of the State University of Ceará, Brazil. The bird presented diarrhea, leg paralysis and anorexia, and died shortly after. Necropsy was then performed and samples from lung, kidney, liver and intestine were collected for microbiological and histopathological analyses. Escherichia coli was isolated from cloacal swab, lung and kidney samples. Salmonella ser. Saintpaul was identified in liver and spleen samples. Escherichia coli isolates were tested for the presence of eight diagnostic genes for diarrheagenic pathotypes (STEC, ETEC, EPEC, EIEC, EAEC) with conventional polymerase chain reaction (PCR). EAEC was detected in the lung and kidney, and STEC in the intestine. In conclusion, Columbina talpacoti is susceptible to enteroaggregative Escherichia coli and Salmonella ser. Saintpaul infection, which may have public health implications.
\end{abstract}

Keywords: Colibacillosis, Salmonellosis, Antimicrobial Resistance

\section{RESUMO}

Este estudo relata um caso de coinfecção por Escherichia coli e Salmonella ser. Saintpaul em uma rolinha-roxa (Columbina talpacoti) recebida pelo Laboratório de Estudos Ornitológicos da Universidade Estadual do Ceará, Brasil. A ave apresentava diarreia, paralisia nas pernas e anorexia, indo a óbito rapidamente. A necropsia foi realizada e amostras de pulmão, rim, fígado e intestino foram coletados para isolamento microbiológico e análise histopatológica. Escherichia coli foi identificada em amostras de suabe cloacal, pulmão e rim. Salmonella ser. Saintpaul foi identificada no fígado e baço. Isolados de E. coli foram testados para a presença de oito genes de diagnóstico para patotipos diarreiogênicos (STEC, ETEC, EPEC, EIEC, EAEC) através de reação em cadeia de polimerase (PCR) convencional. EAEC foi detectada no pulmão e rim, e STEC foi identificada no intestino. Em conclusão, Columbina talpacoti é suscetível a infecção por Escherichia coli enteroagregativa e Salmonella ser. Saintpaul, o que pode implicar em risco para a saúde pública.

Palavras-chave: colibacilose, Salmonelose, Resistência antimicrobiana

\section{INTRODUCTION}

Wild birds are important for public health since they can host and disseminate microbes, such as zoonotic pathogens representing a risk food producing animals (Sousa et al., 2010). Commonly known as ruddy ground dove, the
Columbina talpacoti is found in all the territory from Mexico to Bolivia, Paraguay and Argentina, including Brazil (Sick, 2001). This species is one of the first in Brazil to adapt to urban environments and in search for food, this avian species may perform short migrations and enter broiler chicken houses along with other wild bird species (Sousa et al., 2010).

Recebido em 29 de setembro de 2016

Aceito em 11 de outubro de 2016

E-mail: windleyanne@yahoo.com.br 
This interaction with poultry may pose a risk of transmitting diseases, such as avian colibacillosis, which is distributed worldwide. Different pathologies are associated with E. coli, such as colisepticemia, which presents sudden clinical signs, such as anorexia, ruffled feathers, polyuria, diarrhea and sudden death (Friend and Frason, 1999). Another worrying disease is salmonellosis, caused by bacteria from the genus Salmonella, which is an important public health concern due to the large number of serotypes pathogenic for humans causing a wide variety of symptoms and diseases, including gastrointestinal infections and septicemia (Vidal et al., 2003). Therefore, this study aimed to report the first case of a natural co-infection of $E$. coli and Salmonella ser. Saintpaul in a Columbina talpacoti found in Fortaleza city, Brazil.

\section{CASE DESCRIPTION}

In October 2014, a sub-adult Columbina talpacoti was found in a residence in Fortaleza city, Brazil, and was transported to the Laboratory of Ornithological Studies (LABEO), in the State University of Ceará (UECE) for veterinary care. At clinical evaluation, the bird presented leg paralysis and anorexia. In addition, the presence of dried feces around the cloacae was observed, which indicated severe diarrhea. Then, a cloacal swab was collected for microbiological procedure, following methodology previously used (Bezerra et al., 2016). After sampling, the treatment was initiated with enrofloxacin $(0.04 \mathrm{~mL})$ and ketoprofen $(0.01 \mathrm{~mL})$, which were administered via IM injection. Two hours after the beginning of treatment, the bird died. Necropsy was performed and samples were collected from the following organs for microbiological and histopathological procedure: liver, kidney, lung, spleen and intestine. Microbiological analysis was performed identically as the cloacal swab sample. Isolates that presented biochemical profile compatible with Salmonella sp. were sent to the Laboratory of Enterobacteria part of the Oswaldo Cruz Foundation, which is the reference center in Brazil for confirmation and serotyping. All isolates were inoculated in nutrient agar and, after incubation, maintained refrigerated for further analyses.
Antimicrobial susceptibility test with KirbyBauer disk diffusion technique was performed with the following antibiotics and concentrations: ampicillin $(10 \mu \mathrm{g})$, ceftiofur $(30 \mu \mathrm{g}), \quad$ sulfazotrim (sulfamethoxazole+ trimethoprim) $(25 \mu \mathrm{g})$, sulfonamides $(300 \mu \mathrm{g})$, polymyxin B (300U.I.), gentamycin $(10 \mu \mathrm{g})$, chloramphenicol $(30 \mu \mathrm{g})$, tetracycline $(30 \mu \mathrm{g})$, cefalotin $(30 \mu \mathrm{g})$, norfloxacin $(10 \mu \mathrm{g})$, nalidixic acid $(30 \mu \mathrm{g})$, streptomycin $(300 \mu \mathrm{g})$. After incubation, inhibition zone diameters were measured and compared to standards provided by manufacturers and CLSI (Performance..., 2012).

Histopathological analysis was performed at the Histopathology Laboratory of the Agricultural Sciences Center of the Federal University of Paraiba. Samples from the cerebrum, liver, lung, heart, proventriculus, gizzard, spleen and intestine were collected and preserved in formalin. Then, paraffin blocks were thinly sliced in $5 \mu \mathrm{m}$ thickness, mounted on slides and stained with hematoxylin-eosin.

Molecular analysis was performed at the Laboratory of Molecular Toxinology located in the Federal University of Ceará. Escherichia coli isolates were diagnosed as diarrheagenic based on the presence of eight diagnostic virulence genes from 5 of the $6 \mathrm{E}$. coli pathotypes by means of conventional PCR. Previously described primer sequences were used for the following genes: stx1 (348bp) and stx2 (584bp) for Shiga-toxin producing E. coli-STEC; eltB (508bp) and estA (147bp) for enterotoxigenic $E$. coli - ETEC; eaeA (881bp) for enteropathogenic E. coli-EPEC; ipaH (483bp) for enteroinvasive E. coli - EIEC; and aatA (630bp) and aaiC (215bp) for enteroaggregative E. coli - EAEC (Taniuchi et al., 2012). The strains EAEC 042, EHEC O157:H7, EIEC O124, EPEC 2348/69 and ETEC H10407 were used as positive controls for the reactions. DNA extraction was performed with boiling method. Briefly, isolates were recovered from nutrient agar in BHI broth followed by plating in MacConkey agar and submitted for bacteriological incubation $\left(37^{\circ} \mathrm{C} / 24 \mathrm{~h}\right)$. From each plate, two to three colonies were collected and added to tubes containing $1 \mathrm{~mL}$ of MiliQ water containing Triton $0.5 \%$, homogeneized for $15 \mathrm{~s}$ and heated to $94^{\circ} \mathrm{C}$ for $20 \mathrm{~min}$. Then, tubes were centrifuged at $10.000 \mathrm{rpm}$ for 10min, from which the supernatant containing the extracted DNA was 
collected and analyzed by spectrophotometry using the NanoDrop Spectrophotometer 2000 (Thermo Scientific, Wilmington, USA). PCR reactions were performed with GoTaqGreen (Promega) enzyme and primers at $0.4 \mu \mathrm{M}$ in a thermocycler MyCycler Thermal Cycler (Biorad, CA, EUA) with the following protocol: $95^{\circ} \mathrm{C}$ for $15 \mathrm{~min} ; 40$ cycles of $95^{\circ} \mathrm{C}$ for $30 \mathrm{~s}, 57^{\circ} \mathrm{C}$ for $30 \mathrm{~s}$ and $72^{\circ} \mathrm{C}$ for $1 \mathrm{~min}$; followed by $72^{\circ} \mathrm{C}$ for $10 \mathrm{~min}$. Products were separated in a $2 \%$ agarose gel electrophoresis stained with ethidium bromide and visualized in a transilluminator ChemiDoc XRS System (Biorad, CA, EUA).

Microbiological analysis revealed the presence of $E$. coli in four, out of six analyzed samples: cloacal swab, intestine, lung and kidney. Species were confirmed with a biochemical profile that presented positive for glucose fermentation with gas production, indole, lysine-decarboxylase and methyl red. However, negative for citrate, malonate, Voges-Proskauer reaction and $\mathrm{H}_{2} \mathrm{~S}$ production. Among the analyzed samples, the isolate from the cloacal swab sample was susceptible to eleven out of twelve antibiotics tested, with intermediate resistance to chloramphenicol. However, isolates from extraintestinal organs presented the same antimicrobial susceptibility profile, but different from the intestine isolate (Tab. 1). PCR results revealed the presence of aaiC gene in the isolates from lung and kidney, a marker for EAEC strains, as confirmed by the $215 \mathrm{bp}$ amplicon (Fig. 1). In addition, a 348bp product confirming the stx1 gene was identified in the cloacal swab and intestine samples, which is an indication of STEC (Fig. 2). No unspecific amplification was observed and the remaining genes were not detected in the samples.

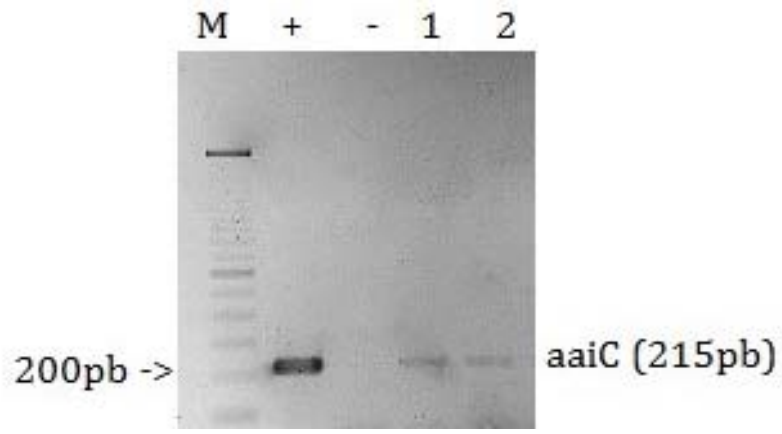

Figure 1. Image of a $2 \%$ agarose gel electrophoresis stained with ethidium bromide. PCR products amplified from DNA samples of E. coli isolated from lung and kidney of Columbina talpacoti, (M) 100pb Molecular marker, (+) positive control - EAEC 042, (-) negative control, (1 and 2); in the numbered columns are the amplified products of the aaiC gene from E. coli isolated from lung and kidney, respectively.

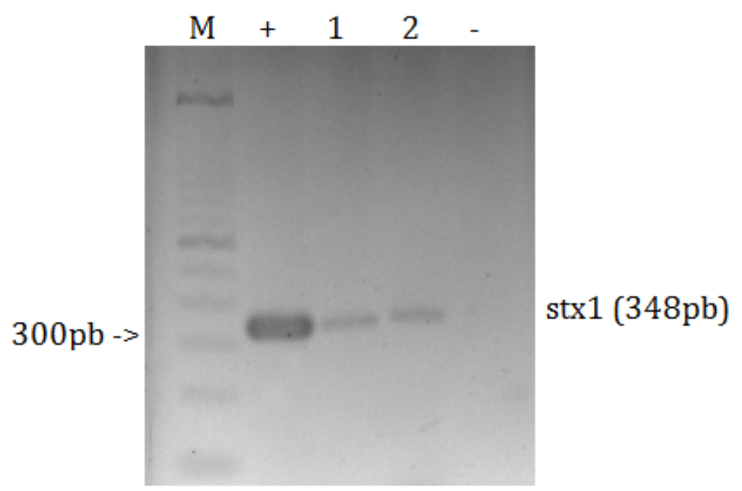

Figure 2. Image of a $2 \%$ agarose gel electrophoresis stained with ethidium bromide. PCR products amplified from DNA samples of E. coli isolated from intestine and cloacal swab of Columbina talpacoti, (M) 100pb Molecular marker, (+) positive control - EHEC O157:H7, (1 and 2); in the numbered columns are the amplified products of the stx 1 gene from E. coli isolated from intestine and cloacal swab, respectively; (-) negative control. 


\section{Escherichia coli and...}

Table 1. Antimicrobial susceptibility profile of E. coli isolated from Columbina talpacoti

\begin{tabular}{lcccc}
\hline Antibiotics & Cloacal swab & Intestine & Lung & Kidney \\
\hline Nalidixic acid & $\mathrm{S}$ & $\mathrm{R}$ & $\mathrm{R}$ & $\mathrm{R}$ \\
Ampicillin & $\mathrm{S}$ & $\mathrm{R}$ & $\mathrm{R}$ & $\mathrm{R}$ \\
Cefalotin & $\mathrm{S}$ & $\mathrm{S}$ & $\mathrm{S}$ & $\mathrm{S}$ \\
Ceftiofur & $\mathrm{S}$ & $\mathrm{S}$ & $\mathrm{S}$ & $\mathrm{S}$ \\
Chloramphenicol & $\mathrm{I}$ & $\mathrm{R}$ & $\mathrm{R}$ & $\mathrm{R}$ \\
Streptomycin & $\mathrm{S}$ & $\mathrm{I}$ & $\mathrm{I}$ & $\mathrm{I}$ \\
Gentamycin & $\mathrm{S}$ & $\mathrm{S}$ & $\mathrm{S}$ & $\mathrm{S}$ \\
Norfloxacin & $\mathrm{S}$ & $\mathrm{R}$ & $\mathrm{R}$ & $\mathrm{R}$ \\
Polymyxin B & $\mathrm{S}$ & $\mathrm{S}$ & $\mathrm{S}$ & $\mathrm{S}$ \\
Sulfazotrim & $\mathrm{S}$ & $\mathrm{R}$ & $\mathrm{R}$ & $\mathrm{R}$ \\
Sulfonamides & $\mathrm{S}$ & $\mathrm{R}$ & $\mathrm{R}$ & $\mathrm{R}$ \\
Tetracycline & $\mathrm{S}$ & $\mathrm{R}$ & $\mathrm{R}$ & $\mathrm{R}$ \\
\hline S: susceptible I & & & &
\end{tabular}

S: susceptible; I: intermediate; R: resistant

Salmonella was isolated from two out of six analyzed samples: liver and spleen. Both isolates were identified as Salmonella enterica subsp. enterica serovar Saintpaul. The antimicrobial susceptibility test revealed a divergence in the profile of both isolates. Liver isolate was susceptible to eleven out of twelve tested antibiotics, and spleen isolate was susceptible to nine (Tab. 2).

Table 2. Antimicrobial susceptibility profile of Salmonella ser. Saintpaul isolated from liver and spleen of Columbina talpacoti

\begin{tabular}{lcccccccccccc} 
& \multicolumn{11}{c}{ Antibiotics } \\
\cline { 2 - 14 } Isolates & NAL & AMP & CFL & CTF & CLO & EST & GEN & NOR & POL & SUL & SUT & TET \\
\hline Liver & S & S & R & S & S & S & S & S & S & S & S & S \\
\hline Spleen & R & S & R & S & I & S & S & R & S & S & S & S \\
\hline
\end{tabular}

$\mathrm{NAL}=$ nalidixic acid $(30 \mu \mathrm{g}), \mathrm{AMP}=$ ampicillin $(10 \mu \mathrm{g}), \mathrm{CFL}=$ cefalotin $(30 \mu \mathrm{g}), \mathrm{CTF}=$ ceftiofur $(30 \mu \mathrm{g}), \mathrm{CLO}=$ chloramphenicol $(30 \mu \mathrm{g}), \mathrm{EST}=$ streptomycin $(10 \mu \mathrm{g}), \mathrm{GEN}=$ gentamycin $(10 \mu \mathrm{g}), \mathrm{NOR}=$ norfloxacin $(10 \mu \mathrm{g}), \mathrm{POL}$ $=$ polymyxin $\mathrm{B}(300 \mathrm{UI}), \mathrm{SUL}=$ sulfonamides $(300 \mu \mathrm{g}), \mathrm{SUT}=$ sulfazotrim $(25 \mu \mathrm{g})$, TET $=$ tetracycline $(30 \mu \mathrm{g})$, $\mathrm{S}$ : susceptible; I: intermediate; R: resistant.

Macroscopic and histopathological findings were more evident in lung, liver and intestine. At necropsy, the left pulmonary lobe presented diffuse edema and congestion, presenting a single focused wide area of hemorrhage. In the same way, liver was diffusely congested with hemorrhagic areas and increased volume. The intestine was diffusely congested with lumen filled with liquid content. Lung slides presented congested pulmonary blood vessels, interstitial and intra-alveolar edema. Liver samples revealed the presence of a wide subcapsular coagulum (hemorrhage), associated with inflammation constituted by heterophils, macrophages and lymphocytes. In addition, random hepatocyte necrotic foci were observed, with some biliary canaliculi dilated by eosinophilic material interpreted as fibrin (Figure 3). Lamina propria of the small intestine was infiltrated by lymphocytes and plasma cells. 

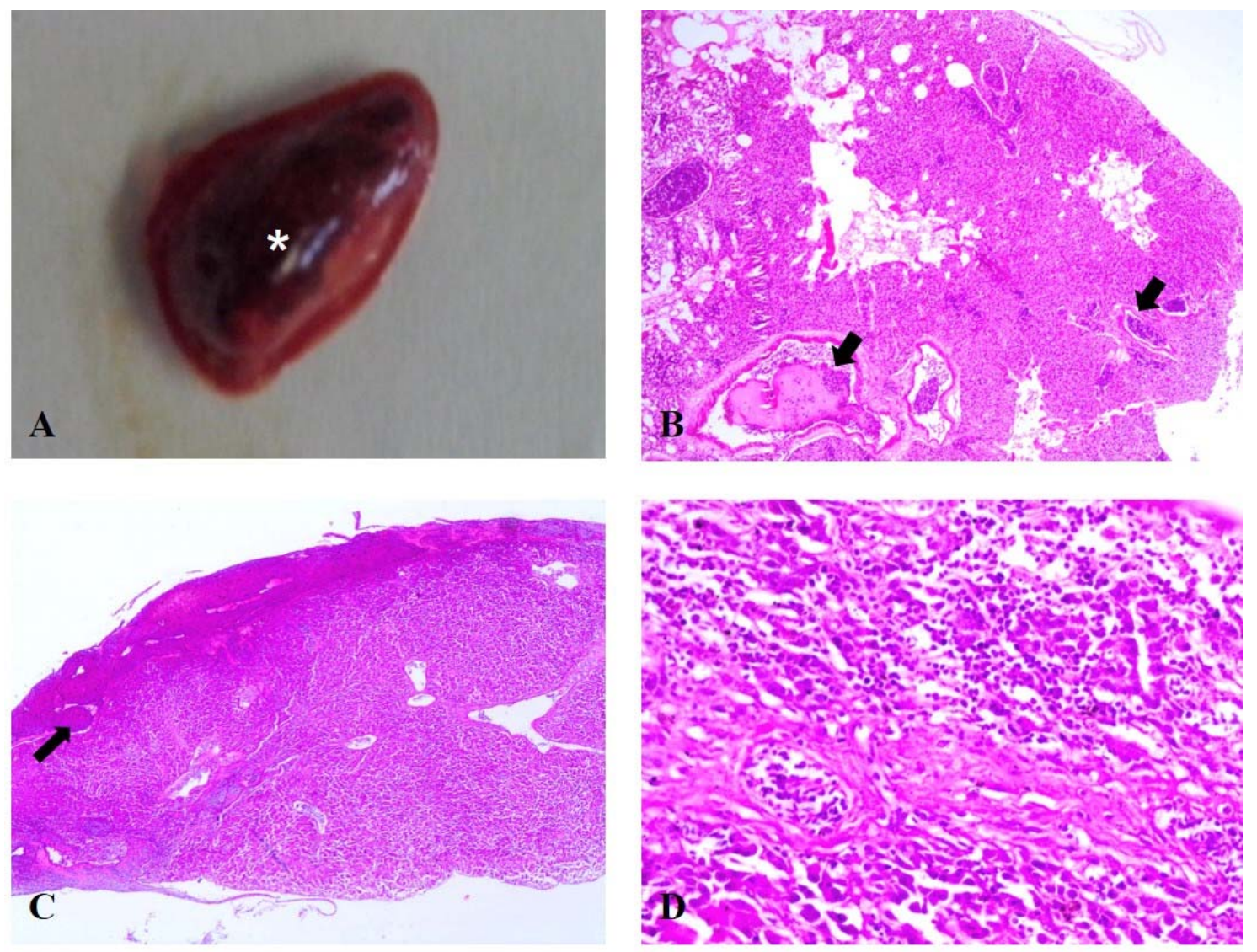

Figure 3. Macroscopic and microscopic alterations of free-living Columbina talpacoti with coinfection of E. coli and Salmonella ser. Saintpaul. Lung, enlarged, edema, diffusely congested and wide hemorrhagic area (asterisk) (A). Lung, congested blood vessels (arrows), intense and diffuse intraalveolar edema. Hematoxylin and eosin (HE), 10x (B). Liver, sub-capsular hemorrhage (arrow). HE, 10x (C). Liver, area of hepatocyte necrosis and infiltration of heterophils, macrophages and lymphocytes. HE, 40x (D).

\section{DISCUSSION}

In the case here reported, salmonella was isolated from organs, however none was isolated from the cloacal swab, which demonstrates that the bird was not shedding this bacterium at the moment and was not a carrier. In addition, this bird was sub-adult and might have acquired the infection from the parents. This possibility may be important since this species is known for a wide range of flight in search for food and may, therefore, spread pathogens in different locations.

Salmonella serotypes have been reported in different species of wild birds in Brazil. In one of these studies, wild birds from 14 different species, including Columbina talpacoti, were captured next to an avian facility and three were positive for salmonella (Sousa et al., 2010). With these results, the authors concluded that there is a potential risk for humans and poultry alike due to the proximity of these birds feeding and defecating close to the poultry houses. Other studies have reported the presence of this species in poultry houses (Horn et al., 2016), which demonstrates the importance of investigating the microbiota of production and wild birds due to the possible contributions in epidemiological studies.

The aaiC gene detected in the E. coli isolates from lung and kidney reveal an alert for the potential reservoir aspect of clinically relevant human enteric pathogens. This is a virulence gene used to diagnose EAEC (Platts-Mills et al., 2015) and is an important part of the type VI secretion system found in this pathogen (Dudley 
et al., 2006). EAEC is an enteric pathogen frequently associated with acute and persistent diarrhea cases in several locations around the world (Okhuysen and Dupont, 2010). The epidemiological importance of EAEC was further demonstrated recently in a multinational and multidisciplinary cohort study involving eight developing countries (Platts-Mills et al., 2015). However, macroscopic and microscopic alterations observed in these organ were unspecific. In addition, respiratory airways are another possible route of penetration, often used by extra-intestinal E. coli. This pathway does not require intestinal colonization or invasion of intestinal epithelium cells and occurs in APEC strains. It has been demonstrated that in regions where air exchange occurs, bacterial colonization and invasion may take place. Then, the pathogen enters the bloodstream through pulmonary capillaries and air sacs (Dho-Moulin and Fairbrother, 1999).

In this report, at the examination, the bird presented evidence of intense diarrhea and no Salmonella sp. was isolated from the intestine or cloacal swab, which may suggest that this finding was caused by the E. coli strain carrying stx1. This gene is an indication of shiga toxinproducing Escherichia coli (STEC), which is an important pathogen for public health since it causes severe diseases in humans. Considering that the microbiota of wild birds are potential reservoirs of virulence genes, our findings suggest that $C$. talpacoti may act as a reservoir and aid in shedding this pathogen among other birds, not necessarily from the same species. In addition, humans may be exposed to this contamination, considering that during sampling, the bird was shedding this microorganism.

The anamnesis, clinical signs, bacterial isolation and necropsy findings support the diagnosis of $E$. coli and Salmonella ser. Saintpaul natural occurring co-infection. A similar report (Dutta et al., 2013) with pigeons necropsied in India diverged from the present study only in the absence of necrohemorrhagic enteritis in $C$. talpacoti.

To the best of the authors' knowledge, this is the first report of a co-infection of Salmonella and $E$. coli in Columbina talpacoti. This study demonstrates that this species is susceptible to these pathogens and can host strains with antimicrobial resistance and virulence genes important for the public health.

Furthermore, we suggest that this species may act as a reservoir of Salmonella ser. Saintpaul, which is an important pathogen in the poultry industry. Therefore, more studies should be performed to elucidate the role of this avian species in the cycles of these diseases.

\section{ACKNOWLEDGMENTS}

We thank the Foundation for the Support of Science Development of Ceará (FUNCAP) for providing the doctorate scholarship and CEFAR ${ }^{\circledR}$ for donating the media necessary for microbiological diagnosis and antimicrobial susceptibility testing discs.

\section{REFERENCES}

BEZERRA, W.G.A.; SILVA, I.N.G.; VASCONCELOS, R.H. et al. Isolation and antimicrobial resistance of Escherichia coli and Salmonella enterica subsp. enterica $(0: 6,8)$ in Broiler Chickens. Acta Sci. Vet., v.44, p.1-7, 2016.

DHO-MOULIN, M.; FAIRBROTHER, J.M. Avian pathogenic Escherichia coli (APEC). Vet. Res., v.30, p.299-316, 1999.

DUDLEY, E.G.; THOMSON, N.R.; PARKHILL, J. et al. Proteomic and microarray characterization of the AggR regulon identifies a pheU pathogenicity island in enteroaggregative Escherichia coli. Mol. Microbiol., v.61, p.12671282, 2006.

DUTTA, P.; BORAH, M.K.; SARMAH, R.; GANGIL, R. Isolation, histopathology and antibiogram of Escherichia coli from pigeons (Columba livia). Vet. World, v.6, p.91-94, 2013.

FRIEND, M.; FRASON, J.C. Field manual of wildlife diseases, general field procedures and diseases of birds. Washington D.C: Geological Survey Madison Wi Biological Resources Div, 1999. 426p.

HORN, T.B.; KÖRBES, J.H.; GRANICH, J. et al. Influence of laying hen systems on the mite fauna (Acari) community of commercial poultry farms in southern Brazil. Parasitol. Re, v.115, p.355-366, 2016. 
OKHUYSEN, P.C.; DUPONT, H.L. Enteroaggregative Escherichia coli (EAEC): a cause of acute and persistent diarrhea of worldwide importance. J. Infect. Dis., v.202, p.503-505, 2010.

PERFORMANCE standards for antimicrobial disk susceptibility tests. M02-A11. Approved Standard. 11.ed. Wayne, PA: CLSI, 2012.

PLATTS-MILLS, J.A.; BABJ, S.; BODHIDATTA, L. et al. Pathogen-specific burdens of community diarrhoea in developing countries: a multisite birth cohort study (MALED). Lancet Glob Health, v.3, p.e564-575, 2015.

SICK, H. Ornitologia brasileira. Rio de Janeiro: Nova Fronteira, 2001.914p.
SOUSA, E.; WERTHER, K.; BERCHIERI JR, A. Assessment of newcastle and infectious bronchitis pathogens, and Salmonella spp. in wild birds captured near poultry facilities. Arq. Bras. Med. Vet. Zootec., v.62, p.219-223, 2010.

TANIUCHI, M.; WALTERS, C.C.; GRATZ, J. et al. Development of a multiplex polymerase chain reaction assay for diarrheagenic Escherichia coli and Shigella spp. and its evaluation on colonies, culture broths, and stool. Diagn. Microbiol. Infect. Dis., v.73, p.121-128, 2012.

VIDAL, J.E.; SILVA, P.R.M.; SCHIAVON NOGUEIRA, R. et al. Liver abscess due to salmonella enteritidis in a returned traveler with HIV infection: case report and review of the literature. Rev. Inst. Med. Trop. São Paulo, v.45, p.115-117, 2003. 